\title{
Fabrication of a Full-Scale Pilot Model of a Cost-Effective Sodium Nickel-Iron Chloride Battery Over 40 Ah
}

\author{
Dong-Geun Lee ${ }^{1}$, Byeong-Min $\mathrm{Ahn}^{2}$, Cheol-Woo Ahn², Joon-Hwan Choi ${ }^{2}$, \\ Dae-Han Lee ${ }^{1 *}$, and Sung-Ki Lim ${ }^{1 * *}$ \\ ${ }^{1}$ Department of Materials Chemistry and Engineering, Konkuk University, 120, Neungdong-ro, Gwangjin-gu, Seoul 143- \\ 701, Korea \\ ${ }^{2}$ Korea Institute of Materials Science (KIMS), Changwon, Gyeongnam, 51508, Korea
}

\begin{abstract}
To fabricate a full-scale pilot model of the cost-effective $\mathrm{Na}-(\mathrm{Ni}, \mathrm{Fe}) \mathrm{Cl}_{2}$ cell, a $\mathrm{Na}$-beta-alumina solid electrolyte (BASE) was developed by applying a one-step synthesis cum sintering process as an alternative to the conventional solid-state reaction process. Also, Fe metal powder, which is cheaper than $\mathrm{Ni}$, was mixed with $\mathrm{Ni}$ metal powder, and was used for cathode material to reduce the cost of raw material. As a result, we then developed a prototype $\mathrm{Na}-$ $(\mathrm{Ni}, \mathrm{Fe}) \mathrm{Cl}_{2}$ cell. Consequently, the $\mathrm{Ni}$ content in the $\mathrm{Na}-(\mathrm{Ni}, \mathrm{Fe}) \mathrm{Cl}_{2}$ cell is decreased to approximately (20 to 50$)$ wt. $\%$. The \#1 prototype cell (dimensions: $34 \mathrm{~mm} \times 34 \mathrm{~mm} \times 235 \mathrm{~mm}$ ) showed a cell capacity of $15.9 \mathrm{Ah}$, and $160.3 \mathrm{mAh}$ $\mathrm{g}^{-1}$ (per the Ni-Fe composite), while the \#2 prototype cell (dimensions: $50 \mathrm{~mm} \times 50 \mathrm{~mm} \times 335 \mathrm{~mm}$ ) showed a cell capacity of $49.4 \mathrm{Ah}$, and $153.2 \mathrm{mAh} \mathrm{g}^{-1}$ at the $2^{\text {nd }}$ cycle.
\end{abstract}

Keywords : Na-Beta Batteries, Sodium Nickel-Iron Chloride Battery, Na-Beta-Alumina, One-Step Synthesis Cum Sintering Process

Received : 19 January 2021, Accepted : 10 March 2021

\section{Introduction}

Because of energy demand and the increase in the price of fossil fuels and corresponding environmental impact, electrochemical energy storage systems or batteries have gained great attention recently for both grid and transportation applications. Among the Battery Energy Storage Systems (BESSs), Na-beta Batteries (NBBs) using a $\mathrm{Na}$-beta-alumina solid electrolyte (BASE) that selectively allows $\mathrm{Na}^{+}$ion transport between a positive electrode and a negative molten sodium electrode have attracted growing interest as grid- and utility-scale batteries [1-5]. In $\mathrm{NBB}$ such as $\mathrm{Na} / \mathrm{S}$ or $\mathrm{Na}-\mathrm{NiCl}_{2}$ batteries, the $\mathrm{Na} / \mathrm{S}$ battery exhibits reasonable power and energy densities, temperature stability, abundant raw materials, system cost, etc. Thus, $\mathrm{Na} / \mathrm{S}$ and Li-ion batteries are

*E-mail address: daehan2@konkuk.ac.kr, sklim@konkuk.ac.kr DOI: https://doi.org/10.33961/jecst.2021.00059

This is an open-access article distributed under the terms of the Creative Commons Attribution Non-Commercial License (http://creativecommons.org/licenses/by-nc/4.0) which permits unrestricted non-commercial use, distribution, and reproduction in any medium, provided the original work is properly cited. currently gaining growing attention in the field of BESS $[2,5,6]$. However, there have been concerns about the safety, and size issues of $\mathrm{Na} / \mathrm{S}$ and Li-ion batteries. The $\mathrm{Na}-\mathrm{NiCl}_{2}$ battery incurs a more expensive system cost than do the $\mathrm{Na} / \mathrm{S}$ and Li-ion batteries. However, compared with the $\mathrm{Na} / \mathrm{S}$ battery, the $\mathrm{Na}-\mathrm{NiCl}_{2}$ battery has some advantages, such as high energy density $\left(120 \mathrm{~W} \mathrm{~h} \mathrm{~kg}^{-1}\right)$, high voltage $(2.58 \mathrm{~V})$, no safety issue, and easy cell assembly process $[1,6-$ 8]. Therefore, many research groups have studied how to resolve the cost issue, such as high operating temperature (approx. $300^{\circ} \mathrm{C}$ ), and the substitution of Ni transition metal powder [8-13].

As mentioned above, there have been many studies of the high temperature $\mathrm{Na}-\mathrm{NiCl}_{2}$ batteries that addressed the challenge of cost issues. First, K-Y. Jung, J-Y. Kim and Guosheng Li et al. have reported the Intermediate Temperature (IT) $\mathrm{Na}-\mathrm{NiCl}_{2}$ battery operating at $190^{\circ} \mathrm{C}$ using bi-layer (e.g., thin dense/ thick porous layers) BASE [9-11]. The advantages of lowering operating temperature are the reduced costs of sealing materials and technologies for the $\mathrm{Na}-$ 
$\mathrm{NiCl}_{2}$ battery system that can employ conventional polymers to replace the complicated and high-cost sealing methods. By having a lower operating temperature, the IT $\mathrm{Na}-\mathrm{NiCl}_{2}$ batteries exhibit a stable cycling performance for over 1,000 cycles, because of the suppression of particle growth in the Ni cathode active materials. Although IT $\mathrm{Na}-\mathrm{NiCl}_{2}$ batteries are in the developmental stage, they offer high promise for large-scale BESS application, because of their easily stackable configuration and simplified cell fabrication process [8-10]. Second, C-W. Ahn and B-M. Ahn et al. have reported the electrochemical properties and cycling performances of $\mathrm{Na}-$ $(\mathrm{Ni}, \mathrm{Fe}) \mathrm{Cl}_{2}$ cells $[12,13]$. To increase cell capacity, as well as reduce Ni content, Fe particles were used that are larger than $\mathrm{Ni}$ particles, reduced $\mathrm{Ni}$ particles by $50 \%$, and obtained significant cell capacity in the $\mathrm{Na}-(\mathrm{Ni}, \mathrm{Fe}) \mathrm{Cl}_{2}$ cell, since $\mathrm{NiCl}_{2}$ layers were not formed on the surface of the $\mathrm{Ni}$ chains during the electrochemical reaction of $\mathrm{Fe}$. In the charge-discharge cycle, $\mathrm{Cl}^{-}$ions are almost consumed by $\mathrm{Fe}$ particles, and then $\mathrm{Ni}$ particles react with the remaining $\mathrm{Cl}^{-}$ions, because the electrochemical potential of $\mathrm{Fe}(2.35 \mathrm{~V})$ is lower than that of the Ni particles $(2.58 \mathrm{~V})$.

Fig. 1 shows a schematic of the full-scale pilot model of the cost-effective $\mathrm{Na}-(\mathrm{Ni}, \mathrm{Fe}) \mathrm{Cl}_{2}$ battery and the overall electrochemical reaction. This cell contains a liquid sodium negative electrode, and the positive electrode consists of a porous structure of $\mathrm{Ni}$, $\mathrm{Fe}$, and $\mathrm{NaCl}$ that is impregnated with $\mathrm{NaAlCl}_{4(1)}$, such as a $\mathrm{Na}^{+}$ion-conducting $2^{\text {nd }}$ electrolyte, BASE as $\mathrm{Na}^{+}$ion-conductor, and an electronic insulant separator. $\mathrm{Na}$-beta-alumina has been the most common choice of the NBBs for a solid electrolyte, primarily because of its high ionic conductivity of $(0.2$ to 0.4$) \mathrm{S}$ $\mathrm{cm}^{-1}$ at $300^{\circ} \mathrm{C}$, excellent compatibility/chemical stability with the electrode materials, satisfactory mechanical strength, and low material cost [14]. There are two parent phases: $\beta$-alumina has the theoretical formula $\mathrm{Na}_{2} \mathrm{O}-11 \mathrm{Al}_{2} \mathrm{O}_{3}$ or $\mathrm{NaAl}_{11} \mathrm{O}_{17}$, whereas $\beta$ "-alumina has the theoretical formula $\mathrm{Na}_{2} \mathrm{O}-5 \mathrm{Al}_{2} \mathrm{O}_{3}$ or $\mathrm{NaAl}_{5} \mathrm{O}_{8}$, which have ionic conductivity of $(0.03$ and 0.2$) \mathrm{S} \mathrm{cm}^{-1}$ at $350^{\circ} \mathrm{C}$, respectively [15-17]. According to the $\mathrm{Na}_{2} \mathrm{O}-\mathrm{Al}_{2} \mathrm{O}_{3}$ phase diagram proposed by Fally et al. [18], $\beta-+\beta$ "-alumina phases coexist in that region corresponding to the formula $\mathrm{Na}_{2} \mathrm{O} \cdot n \mathrm{Al}_{2} \mathrm{O}_{3}$, where $(5.33 \leq n \leq 8.5)$. The $\beta$ and $\beta^{\prime \prime}$-alumina phases have close-packed structures

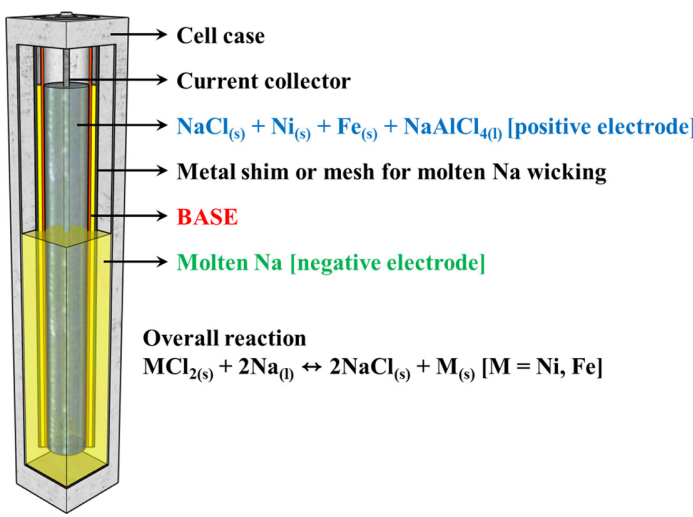

Fig. 1. Schematic cross-section of the $\mathrm{Na}-(\mathrm{Ni}, \mathrm{Fe}) \mathrm{Cl}_{2}$ battery.

with two and three spinel blocks, respectively, separated by conduction planes containing sodium and oxygen. $\beta$ "-alumina has a rhombohedral structure with an $\mathrm{R} \overline{3} \mathrm{~m}$ space group and lattice constants of $a$ and $c$ of (5.614 and 33.85) $\AA$, respectively [14]. A unit cell of $\beta^{\prime \prime}$-alumina consists of a three-fold screw axis using three spinel blocks, and each spinel block is separated by a conduction plane linked to the alkali-ion layer and the $\mathrm{Al}-\mathrm{O}-\mathrm{Al}$ combination layer. In general, its $a$-axis is similar to that of $\beta$-alumina, whereas its $c$-axis is 1.5 times longer, and the concentration of alkaline ions on its conduction plane is higher. Therefore, the $\beta^{\prime \prime}-\mathrm{Al}_{2} \mathrm{O}_{3}$ exhibits substantially higher ionic conductivity $[19,20]$.

The fabrication of BASE can be roughly categorized into two types: solid-state reaction processes, i.e., the conventional process, and soft-chemistry routes, such as sol-gel $[7,15,16]$ or co-precipitation [21-24]. The ionic conductivity of soft-chemistry routes was reported $0.38 \mathrm{~S} \mathrm{~cm}^{-1}$ at $300^{\circ} \mathrm{C}$ by Sandeep P. Butee et al. [22] and $0.21 \mathrm{~S} \mathrm{~cm}^{-1}$ at $350^{\circ} \mathrm{C}$ by ShiJie Shan et al. [23]. Although soft-chemistry methods could be used to mix the reactants on a molecular scale to ensure high reactivity and thus obtain nanoscale powder and a high-quality product, it is generally difficult to scale up such methods for industrial mass production. The conventional process is essential for the fabrication of BASE. Unfortunately, in the conventional process, the preliminary calcination step to obtain a $\mathrm{Na}$-beta-alumina powder increases the complexity of the fabrication steps, energy consumption, and total manufacturing cost. Hence, in the 

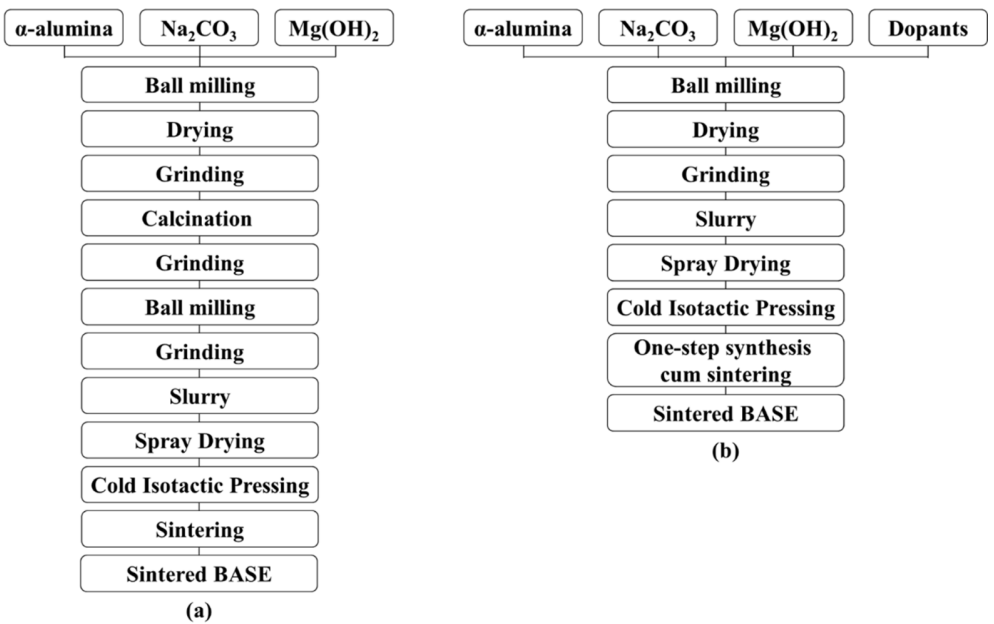

(b)

Fig. 2. Schematics of the BASE manufacturing method by the (a) conventional process, and (b) one-step synthesis cum sintering process.

manufacturing of NBBs, it would be beneficial to decrease the number of production steps and produce a BASE more efficiently. When the production of BASE by direct firing is attempted without calcination, severe volume expansion occurs in the phase transition from $\alpha$ - to $\beta / \beta^{\prime \prime}$-alumina, making it difficult to obtain a BASE with uniform quality and high strength. To overcome these shortcomings, we need to study the improvement of properties by adding dopants. In the present work, we prepared a costeffective BASE by applying a one-step synthesis cum sintering process without a Na-beta-alumina calcination step. Fig. 2 shows schematics of the conventional and a one-step synthesis cum sintering processes for BASE. Furthermore, we attempted to make for the first time a full-scale pilot model of $\mathrm{Na}-$ $(\mathrm{Ni}, \mathrm{Fe}) \mathrm{Cl}_{2}$ cell over $40 \mathrm{Ah}$, which uses a ferro-nickel chloride as cathode material.

\section{Experimental}

\subsection{Cathode materials preparation}

The cathode active materials were prepared using Ni (99.7\%, $2.5 \mu \mathrm{m}$, Standard Grade, Value), Fe (99.5\%, $6.5 \mu \mathrm{m}$, International Specialty Products), and $\mathrm{NaCl}$ (98\%, Sigma-Aldrich) powders. The weight ratios of $\mathrm{NaCl} /(\mathrm{Ni}+\mathrm{Fe})$ were approximately $58.8 \%(1.0 \mathrm{~g} / 1.7 \mathrm{~g})$. Thus, the theoretical capacity of the cell is approximately $275 \mathrm{mAh} \mathrm{g}^{-1}$ (per weight of $\mathrm{Ni}, \mathrm{Fe}$ powders). Two mixtures of $\mathrm{Ni}$ and Fe powders were used, namely, $\mathrm{Ni} / \mathrm{Fe}=(0.8 / 0.2$ and $0.5 / 0.5) \mathrm{wt} /$ wt. Then, the cathode active materials were prepared using plate-type granules by a roller compactor. The cathode active materials were provided by the Korea Institute of Materials Science (KIMS, Korea) $[12,13]$. The $\mathrm{NaAlCl}_{4}$ (the $2^{\text {nd }}$ electrolyte) melt was synthesized at $250{ }^{\circ} \mathrm{C}$, using $\mathrm{NaCl}$ and $\mathrm{AlCl}_{3}$ (99.985\%, Alfa Aesar) powder, then added Sulfur (Sigma-Aldrich) powder of $5 \mathrm{wt} . \%$ to the $\mathrm{NaAlCl}_{4}$ powder in a glove box. Sulfur powder has been used to remove the oxide layers from the surface of the $\mathrm{Ni}$ and Fe metal particles [25].

\subsection{Preparation of BASE applying a one-step syn- thesis cum sintering process}

BASE was fabricated using commercial $\alpha-\mathrm{Al}_{2} \mathrm{O}_{3}$ (99.9\%, High Purity Chemicals, Japan), $\mathrm{Na}_{2} \mathrm{CO}_{3}$ (99.8\%, Sigma-Aldrich, USA), $\mathrm{Mg}(\mathrm{OH})_{2}(99 \%$, Sigma-Aldrich, USA), Yttria Stabilized Zirconia (YSZ; 99.9\%, High Purity Chemicals, Japan), $\mathrm{Ta}_{2} \mathrm{O}_{5}$ (99.9\%, High Purity Chemicals, Japan), and $\mathrm{MnO}_{2}$ (99.99\%, High Purity Chemicals, Japan) powders as the starting materials. The fabricated BASE contained $\mathrm{Na}_{2} \mathrm{O}$ at the $\left[\mathrm{Na}_{2} \mathrm{O}\right] /\left[\mathrm{Al}_{2} \mathrm{O}_{3}\right]$ molar ratio of $1 /$ 6.1, 4.1 wt. $\% \mathrm{MgO}$ (as a stabilizer), 0.8 wt.\% $\mathrm{MnO}_{2}$ (as a dopant), 0.3 wt.\% $\mathrm{Ta}_{2} \mathrm{O}_{5}$ (as a dopant), and 8.0 wt.\% YSZ (as a dopant). The raw materials were ball milled for $5 \mathrm{~h}$. Before spray-drying, the slurries were ball-milled for $12 \mathrm{~h}$. The slurries used in the granulation step contained $3.0 \mathrm{wt}$.\% polyvinyl alco- 

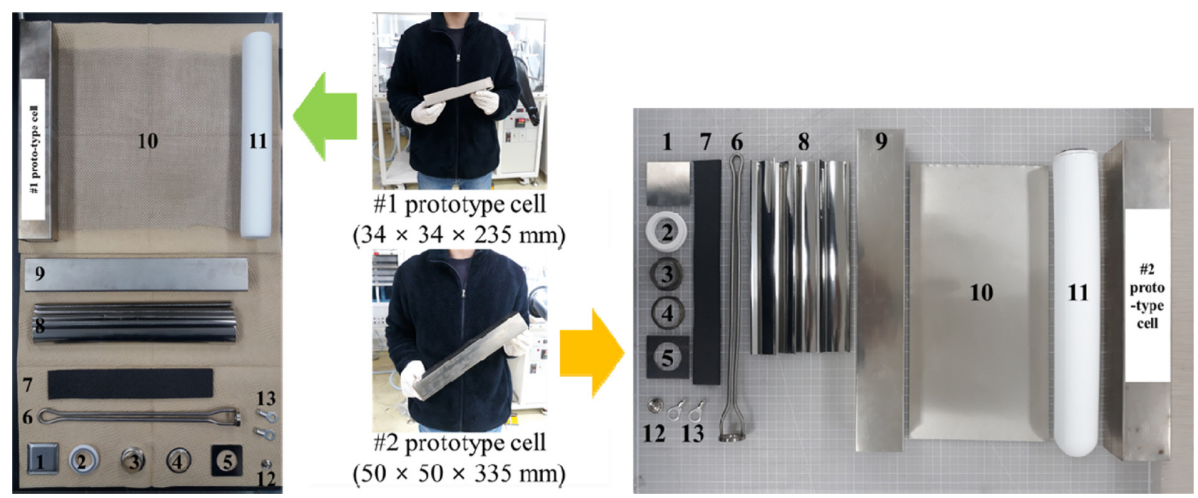

Fig. 3. Image of cell components of \#1 prototype cell, and \#2 prototype cell; 1 . bottom case, 2 . $\alpha$-alumina ring, 3 . inner $\mathrm{Ni}$ ring, 4. outer Ni ring, 5. upper case, 6. Ni current collector, 7. carbon felt, 8. shims, 9. cell case, 10. metal mesh or foil, 11. BASE (Na-beta-alumina solid electrolyte), 12. inner cap, 13. terminals

hol binder (SAN NOPCO, BD-25, Japan), and 1.0 wt.\% dispersant (SAN NOPCO, 44-CF, Japan) for the net weight of raw materials powder in distilled water. Then, they were spray-dried using a disk-type spray dryer, where the inlet and outlet temperatures were set at $(180 \text { and } 110)^{\circ} \mathrm{C}$, respectively. After the spray-drying process, only granules that passed through a 100 mesh $(149 \mathrm{~mm})$ sieve were collected. The collected granules were cold isotactic pressed (CIP) at $120 \mathrm{MPa}$ using a CIP mold, and green tubes were sintered in a furnace for $120 \mathrm{~min}$ at $1,620^{\circ} \mathrm{C}$.

\subsection{Full-scale pilot model of the $\mathrm{Na}-(\mathrm{Ni}, \mathrm{Fe}) \mathrm{Cl}_{2}$ battery assembly and cell cycling}

Fig. 3 shows that the cell components of the \#1 prototype cell and \#2 prototype cell (\#1 cell: $34 \mathrm{~mm}$ $\times 34 \mathrm{~mm} \times 235 \mathrm{~mm}$; \#2 cell: $50 \mathrm{~mm} \times 50 \mathrm{~mm} \times$ $335 \mathrm{~mm}$ ) consist of a cell case (Ni metal), fabricated BASE, metal mesh or foil (Ni metal), wicking shim (Ni metal), current collector (Ni metal), carbon felt, $\alpha$-alumina ring, etc., and the fabricated cell image of the prototype cells. The $\# 2$ prototype cells were fabricated (e.g., \#2-1 prototype cell, \#2-2 prototype cell). The $\alpha$-alumina/Ni ring joints were applied with thermal compression bonding (TCB). The fabricated BASE was glass-sealed to the $\alpha$-alumina/Ni ring joints, and then heat treated the BASE/ $\alpha-$ alumina joints at $1,000^{\circ} \mathrm{C}$ for $30 \mathrm{~min}$ using a box furnace. For carbon coating, the carbon paste was spread onto the anode side of BASE, and heat treated the BASE/ $\alpha-$ alumina joints at $270^{\circ} \mathrm{C}$ for $5 \mathrm{~min}$ to remove impurities [26]. The carbon felt was placed in the current collector, and then, the Ni metal components (e.g., cell case, top/bottom cell cover, BASE/ $\alpha$-alumina joints) were fabricated by using a laser welding machine. The fabricated fixture were transferred into a glove box for the cell assembly. Cathode granules (e.g., cathode active materials) were added to the cathode side of the fabricated fixture, and $\mathrm{NaAlCl}_{4}$ melt was infiltrated into the cathode granules at an elevated temperature of $250^{\circ} \mathrm{C}$. Finally, the fixture was enclosed with Ni metal inner cap by laser welding. The fabricated full-scale pilot model of $\mathrm{Na}-$ $(\mathrm{Ni}, \mathrm{Fe}) \mathrm{Cl}_{2}$ cells was cycled at an elevated temperature of $300^{\circ} \mathrm{C}$ using a heating chamber (Jeio Tech, Korea). All cell cycling tests were conducted using a 4,300 K Battery Test System (Maccor Inc., USA).

\section{Results and Discussion}

In the microstructure design of cathode active material, the connection of Ni particles must be considered to obtain high electronic conductivity, as shown in Fig. 4 [13]. The cathode active materials were designed for the $\mathrm{Fe}$ particles to be larger than the Ni particles, since by using large $\mathrm{Fe}$ particles, $\mathrm{Ni}$ particles could be well-connected. Fig. 5 shows the microstructures of the $\mathrm{Ni}$ and Fe particles [13]. The particle size of the agglomerated Fe metal (approx. $6.5 \mu \mathrm{m}$ ) was larger than the Ni metal (approx. $500 \mathrm{~nm})$.

In previous work, we have reported the fabrication of BASE to increase the sintered properties using the addition of various dopants [27-32]. Table 
1 summarizes the characteristics of the BASE with various dopants added. The improvements in the sintered densities of the BASE are the result of the increasing concentrations of $\mathrm{Al}^{3+}$ ion vacancies in the spinel block; these vacancies promote densification by providing a diffusion path for $\mathrm{Al}^{3+}$ ions [31]. The sintered densities of Si- and Ti-doped BASE were improved by doping with small amounts of $\mathrm{SiO}_{2}$ and $\mathrm{TiO}_{2}$. The increase in densification with $\mathrm{SiO}_{2}$ and $\mathrm{TiO}_{2}$ content occurred partly from the effect of the liquid phase in allowing the rearrangement of the particles. A liquid phase creates an attractive force between the particles, putting the particle contacts in compression [29,31]. In the YSZ-, CSZ-doped BASE, the sintered densities increased with the addition of each dopant content. Generally, in the range of pure BASE to $21 \mathrm{wt} \%$ zirconia addition, the sin-

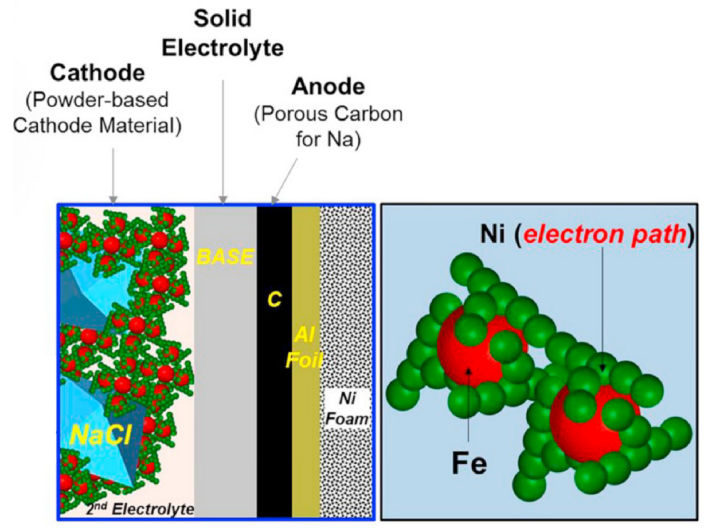

Fig. 4. Schematic of the designed microstructure of Ni-Fe metal-composite powders (derived from Ref. 13). tered density of the YSZ-, CSZ-doped BASE increased with the zirconia content, indicating that the addition of zirconia particles allowed the densification of the alumina matrix; the volume expansion from tetragonal to monoclinic associated with the phase transformation improved the sintered density (CSZ, YSZ) [30,32]. In the case of Mn-doped BASE, $\mathrm{Mn}^{2+}$ or $\mathrm{Mn}^{3+}$ ions were substituted for $\mathrm{Al}^{3+}$ ion in the tetrahedral sites of the spinel blocks. The resulting charge defects were compensated for by the additional $\mathrm{Na}^{+}$ions in the conduction planes, which resulted in a higher $\mathrm{Na}^{+}$ion concentration and $\beta "-$ $\mathrm{Al}_{2} \mathrm{O}_{3}$ phase fraction [28]. The ionic conductivity of BASE was affected by the sintered density and the $\beta "-\mathrm{Al}_{2} \mathrm{O}_{3}$ phase fraction. As experimental results, the sintered density was the main factor causing an increase in the ionic conductivity of the BASE. In

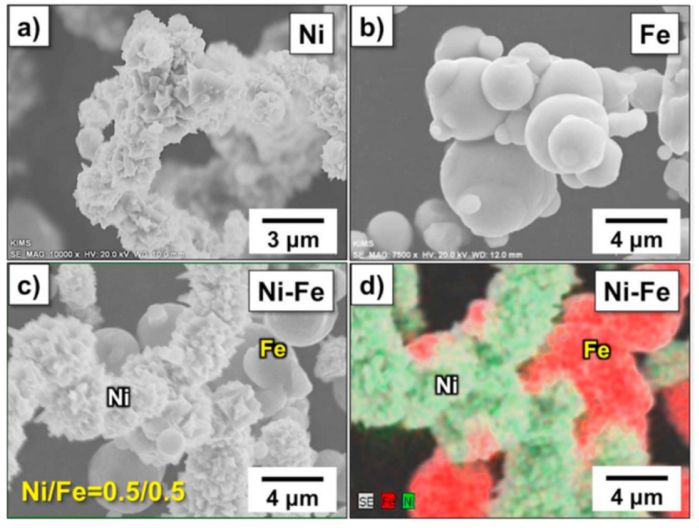

Fig. 5. SEM images of (a) $\mathrm{Ni}$, (b) $\mathrm{Fe}$, (c) \& (d) Ni-Fe powders (derived from Ref. 13).

Table 1. Summary of the characteristics of the sintered properties, secondary phase, and grain growth possibility of the sintered BASE with various dopants.

\begin{tabular}{|c|c|c|c|c|c|c|}
\hline Dopant & $\begin{array}{l}\text { Sintered density } \\
\text { (improvement) }\end{array}$ & $\begin{array}{c}\beta " \text {-phase fraction } \\
\text { (improvement) }\end{array}$ & $\begin{array}{l}\text { Ionic conductivity } \\
\text { (improvement) }\end{array}$ & Secondary phase & $\begin{array}{l}\text { Abnormal } \\
\text { grain growth }\end{array}$ & Ref. \\
\hline $\mathrm{Si}$ & $\bigcirc$ & None & $\bigcirc$ & $\mathrm{NaAlO}_{2}, \mathrm{SiO}_{2}$ & $\bigcirc$ & [29] \\
\hline $\mathrm{Ca}$ & $\triangle$ & None & None & $\mathrm{Na}_{4} \mathrm{Ca}_{3}\left(\mathrm{AlO}_{2}\right)_{10}$ & 0 & [27] \\
\hline $\mathrm{Ti}$ & $\bigcirc$ & 0 & 0 & None & $\bigcirc$ & [31] \\
\hline $\mathrm{Mn}$ & $\triangle$ & () & $\triangle$ & None & None & [28] \\
\hline $\mathrm{Fe}$ & $\triangle$ & 0 & $\triangle$ & None & None & [31] \\
\hline $\mathrm{Ta}$ & None & None & (a) & Unknown phase & None & - \\
\hline YSZ & () & None & None & None & None & [32] \\
\hline $\mathrm{CSZ}$ & () & None & None & $\mathrm{Na}_{4} \mathrm{Ca}_{3}\left(\mathrm{AlO}_{2}\right)_{10}$ & None & [32] \\
\hline
\end{tabular}




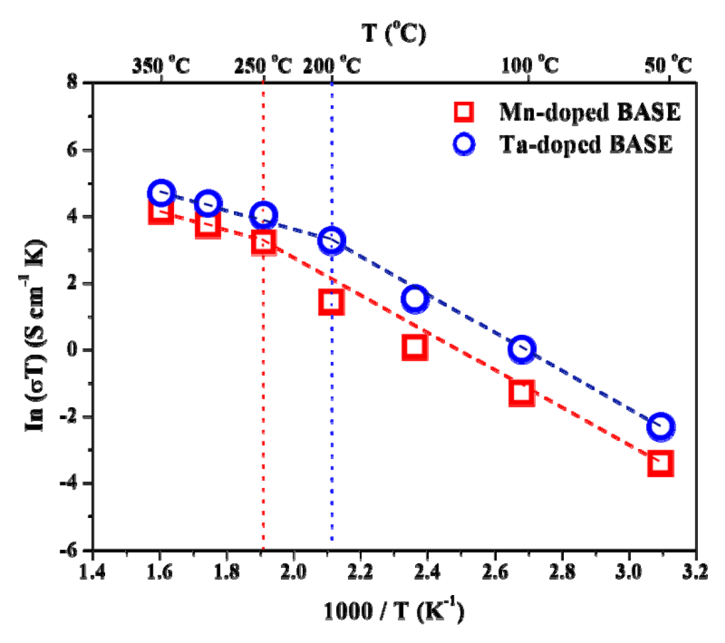

Fig. 6. Arrhenius plots for the Mn-doped and Ta-doped $\mathrm{Na}$-beta-alumina sintered specimen

general, polycrystalline BASE has grain bulk resistance $\left(R_{B}\right)$ and grain boundary resistance $\left(R_{G B}\right)$; so it was possible to separate out the semi-circle part and the line part below $250^{\circ} \mathrm{C}$ [29]. Above $250^{\circ} \mathrm{C}$, the grain boundary resistance to the total resistance was negligible; then at $250^{\circ} \mathrm{C}$, the inflection point appeared in the Arrhenius plots, and the activation energy declined as the temperature rose above the inflection point. In the case of Si-, Ti-, Mn-, Fe-doped BASE, the inflection points appeared at (220 to $250)^{\circ} \mathrm{C}[28,29,31]$. In the case of Ta-doped BASE, on the other hand, the inflection point appeared at $200^{\circ} \mathrm{C}$, which means the grain boundary resistance significant declined with the addition of Ta dopant (shown in Fig. 6). In fact, the addition of Ta to BASE by applying a one-step synthesis cum sintering process has not previously been reported. In the case of Ta-doped BASE, we can deduce that a specific amount of $\mathrm{Ta}^{5+}$ ions can enter the spinel block; then in the firing step, the residual $\mathrm{Ta}^{5+}$ ions tend to concentrate on the grain boundaries. The abnormal grain growth (mainly caused by liquid-phase sintering) during the firing step may significantly affect the mechanical strength of BASE. Given the results mentioned above, we fabricated BASE containing some dopants (e.g., Mn, Ta, YSZ), by applying a one-step synthesis cum sintering process. In the BASE fabricated by applying a one-step synthesis cum sintering process, the mechanical strength and ionic conductivity increased with lower porosity and higher sintered density. The bending strength and specific resistance at $350^{\circ} \mathrm{C}$ were $314 \mathrm{MPa}$ (authorized test, Korea Institute of Ceramic Engineering and Technology, KICET, Korea) and $5.67 \Omega \mathrm{cm}$ (authorized test, Korea Institute of Energy Research, KIER, Korea), respectively.

The \#1 and \#2 prototype cells were fabricated using dopants doped-BASE, (Ni, Fe) cathode active material, and $\mathrm{NaAlCl}_{4} 2^{\text {nd }}$ electrolyte. Each cell was cycled with discharging and charging currents of $(0.2,0.4$, and 0.8$) \mathrm{A}$. The theoretical capacities of these cells are approximately $275 \mathrm{mAh} \mathrm{g}^{-1}$ (per the weight of $\mathrm{Ni}, \mathrm{Fe}$ powders). The \#1 prototype cell showed a charge capacity of $18.0 \mathrm{Ah}\left(181.5 \mathrm{mAh} \mathrm{g}^{-1}\right)$ and discharge capacity of $15.9 \mathrm{Ah}\left(160.3 \mathrm{mAh} \mathrm{g}^{-1}\right)$. The \#2-1 prototype cell showed a charge capacity of 55.2 Ah (171.2 $\left.\mathrm{mAh} \mathrm{g}^{-1}\right)$ and discharge capacity of 48.4 Ah (150.1 $\left.\mathrm{mAh} \mathrm{g}^{-1}\right)$. The charge and discharge capacity were increased approximately 3 times by cell volume extension; however, the capacity per $\mathrm{M}$ (e.g., Ni, Fe) weight was decreased by approximately $\sim 7 \%$, because the theoretical capacity of $\mathrm{Fe}$ is higher than that of $\mathrm{Ni}[12,13]$. Also, as the cell size increased, the difficulty of the $\mathrm{NaAlCl}_{4}$ melt soaking process in the cell fabrication process significantly increased. In the case of the $\mathrm{Na}-(\mathrm{Ni}, \mathrm{Fe}) \mathrm{Cl}_{2}$ cell assembly process, it is important to control the influence of the contact characteristics between the NaAl$\mathrm{Cl}_{4} 2^{\text {nd }}$ electrolyte and the cathode active material. Considering the energy and energy density of the cells, those values of the high Ni content cell were increased, although the capacity per $\mathrm{M}$ (e.g., Ni, Fe) was higher with the $\mathrm{Ni} / \mathrm{Fe}=0.5 / 0.5$ composition cell than with the $\mathrm{Ni} / \mathrm{Fe}=0.8 / 0.2$ composition cell. The \#2-2 prototype cell showed a charge capacity of 48.7 Ah (151.1 $\left.\mathrm{mAh} \mathrm{g}^{-1}\right)$, discharge capacity of 49.4 Ah (153.2 $\left.\mathrm{mAh} \mathrm{g}^{-1}\right)$, and Coulombic efficiency of $101.4 \%$. The charge-discharge capacity of the $\mathrm{Na}-$ $(\mathrm{Ni}, \mathrm{Fe}) \mathrm{Cl}_{2}$ cell was approximately $(57-65) \%$ $\left(263 \mathrm{~m} \mathrm{Ah} \mathrm{g}^{-1} ; 2^{\text {nd }}\right.$ cycle, theoretical capacity, $314 \mathrm{mAh} \mathrm{g}^{-1}$ ), compared to that of the $1.5 \mathrm{NF}$ KIMS simple test cells (e.g., weight ratios of $\mathrm{NaCl} / \mathrm{Ni}-\mathrm{Fe}$ such as 1.0/1.5) [13]. Table 2 compares the chargedischarge capacities and energy densities etc., of the \#1 and \#2 prototype cells. Fig. 7 shows the detailed voltage profiles of the \#1 and \#2 prototype cells. Comparison of these voltage profiles of the \#1 and \#2-1 prototype cells showed that the \#1 prototype voltage profile revealed low voltage curves, com- 
Table 2. Comparison of the values of the charge/discharge capacity and charge/discharge energy.

\begin{tabular}{|c|c|c|c|c|c|c|c|c|}
\hline & $\begin{array}{c}\text { A.M }^{1)} \\
\text { composi-tion }\end{array}$ & $\begin{array}{l}\text { Weight of } \\
\text { A.M, g }\end{array}$ & Current, A & Capacity, Ah & $\begin{array}{l}\text { Capacity, } \\
\left.\mathrm{mAh} / \mathrm{g}^{2}\right)\end{array}$ & $\begin{array}{c}\text { C.E, }{ }^{3)} \\
\%\end{array}$ & Energy, Wh & $\begin{array}{l}\text { Energy } \\
\text { density, } \\
\left.\mathrm{Wh} / \mathrm{kg}^{4}\right)\end{array}$ \\
\hline $\begin{array}{l}\# 1 \text { cell, } \\
2^{\text {nd }} \text { cycle }\end{array}$ & $\begin{array}{l}\mathrm{Ni} / \mathrm{Fe}= \\
0.5 / 0.5\end{array}$ & 160 & 0.2 & $\begin{array}{l}\text { C.C: } 18.0 \\
\text { D.C: } 15.9\end{array}$ & $\begin{array}{l}\text { C.C: } 181.5 \\
\text { D.C: } 160.3\end{array}$ & 88.3 & $\begin{array}{l}\text { C.E: } 42.6 \\
\text { D.E: } 33.0\end{array}$ & $\begin{array}{l}\text { C: } 79.9 \\
\text { D: } 61.9\end{array}$ \\
\hline $\begin{array}{l}\# 2-1 \text { cell, } \\
2^{\text {nd }} \text { cycle }\end{array}$ & $\begin{array}{l}\mathrm{Ni} / \mathrm{Fe}= \\
0.8 / 0.2\end{array}$ & 520 & 0.4 & $\begin{array}{l}\text { C.C: } 55.2 \\
\text { D.C: } 48.4\end{array}$ & $\begin{array}{l}\text { C.C: } 171.2 \\
\text { D.C: } 150.1\end{array}$ & 87.7 & $\begin{array}{l}\text { C.E: } 146.5 \\
\text { D.E: } 119.0\end{array}$ & $\begin{array}{l}\text { C: } 104.6 \\
\text { D: } 85.0\end{array}$ \\
\hline $\begin{array}{l}\# 2-2 \text { cell, } \\
2^{\text {nd }} \text { cycle }\end{array}$ & $\begin{array}{l}\mathrm{Ni} / \mathrm{Fe}= \\
0.8 / 0.2\end{array}$ & 520 & 0.8 & $\begin{array}{l}\text { C.C: } 48.7 \\
\text { D.C: } 49.4\end{array}$ & $\begin{array}{l}\text { C.C: } 151.1 \\
\text { D.C: } 153.2\end{array}$ & 101.4 & $\begin{array}{l}\text { C.E: } 132.7 \\
\text { D.E: } 113.1\end{array}$ & $\begin{array}{l}\text { C: } 94.8 \\
\text { D: } 80.8\end{array}$ \\
\hline
\end{tabular}

${ }^{1)}$ A.M: cathode active materials

${ }^{2)} \mathrm{mAh} \mathrm{g}^{-1}$ : per weight of $\mathrm{Ni}, \mathrm{Fe}$ powders

${ }^{3)}$ C.E: Coulombic Efficiency

${ }^{4}$ Net weight of \#1 and \#2 prototype cell is approximately $0.53 \mathrm{~kg}$ and $1.38 \mathrm{~kg}$, respectively.

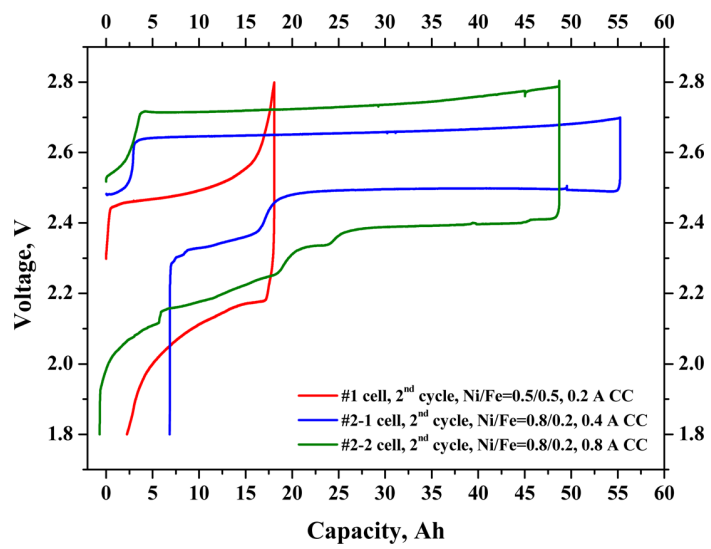

Fig. 7. Voltage profiles for the $\# 1$ and $\# 2$ prototype $\mathrm{Na}-$ $(\mathrm{Ni}, \mathrm{Fe}) \mathrm{Cl}_{2}$ cells with different charging/discharging current of (0.2-0.8) A.

pared to the \#2 prototype cell. The \#2-2 prototype cell showed a much higher over-potential compared to the \#2-1 prototype cell, resulting from the predominant cause of the high ohmic resistance of the cell, or the internal issue of cathode part (such as contact characteristics, or Ni poisoning by residual oxygen). The plateau of over $2.75 \mathrm{~V}$ in the charging cycle occurred by the effect of the overcharge reaction of Fe with $\mathrm{NaAlCl}_{4}$ melt in the Fe-added $\mathrm{Na}-\mathrm{NiCl}_{2}$ cells. In order to avoid $\mathrm{Fe}$ overcharge reaction, the cut-off voltage of the charging cycle was preferred from (2.8 to 2.7$) \mathrm{V}$.

\section{Conclusions}

In this study, we present the first successful realiza- tion by a domestic technology of a full-scale pilot model of a cost-effective $\mathrm{Na}-(\mathrm{Ni}, \mathrm{Fe}) \mathrm{Cl}_{2}$ battery over $40 \mathrm{Ah}$. One of the most challenging issues in the present study results is the higher over-potential in charge-discharge cycling at a low current rate; this is related to the cell ohmic resistance (e.g., BASE, $\mathrm{NaAlCl}_{4}$ melts, cell components etc.) and, as mentioned above, the internal issue of the cathode part. This paper provides information for each material for the $\mathrm{Na}-(\mathrm{Ni}, \mathrm{Fe}) \mathrm{Cl}_{2}$ battery technology and the challenges ahead for further technology enhancement.

\section{Conflict of interest}

The authors declare that they have no conflict of interest.

\section{Acknowledgements}

This work was supported by a Korea Institute of Energy Technology Evaluation and Planning (KETEP) grant funded by the Korea government (No. 20172420108430, Development of high-capacity technology of high-safety sodium-ferronickel chloride battery). This paper was supported by Konkuk University Researcher Fund in 2019.

\section{References}

[1] J.L. Sudworth, J. Power Sources., 1994, 51(1-2), 105114.

[2] T. Oshima, M. Kajita, A. Okuno, Int. J. Appl. Ceram. Technol., 2004, 1(3), 269-276.

[3] Daniel H. Doughty, Paul C. Butler, Abbas A. Akhil, Nancy H. Clark, John D. Boyes, J. Electrochem Soc 
Interface., 2010, 19(3), 49-53.

[4] Z. Yang, J. Zhang, M.C.W. Kintner-Meyer, X. Lu, D. Choi, J.P. Lemmon, J. Liu, Chem. Rev., 2011, 111(5), 3577-3613.

[5] J. E. Battles, Int. Mater. Rev., 1989, 34(1), 1-18.

[6] K. B. Hueso, M. Armand, T. Rojo, Energy Environ. Sci., 2013, 6(3), 734-749.

[7] T. M. O'Sullivan, C. M. Bingham and R. E. Clark, International Symposium on Power Electronics Electric Drives Automation and Motion (SPEEDAM), Institution of Electronic and Electrical Engineers., 2006.

[8] H. J. Chang, X. Lu, J. F. Bonnett, N. L. Canfield, S. Son, Y. Park, K. Jung, V. L. Sprenkle, G. Li, J. Power Sources., 2017, 348, 150-157.

[9] J.Y. Kim, N.L. Canfield, J.F. Bonnett, V.L. Sprenkle, K. Jung, I. Hong, Solid State Ionics., 2015, 278, 192-197.

[10] K. Jung, H. Chang, Jeffery F. Bonnett, Nathan L. Canfield, Vincent L. Sprenkle, Guosheng Li, J. Power Sources., 2018, 396, 297-303.

[11] Guosheng Li, X. Lu, Jin Y. Kim, Kerry D. Meinhardt, Hee Jung Chang, Nathan L. Canfield \& Vincent L. Sprenkle, Nat. Commun., 2016, 7(1), 1-6.

[12] C. W. Ahn, M. Kim, B. D. Hahn, I. C. Hong, W. S. Kim, G. Y. Moon, H. S. Lee, K. Y. Jung, Y. C. Park, J. H. Choi, J. Power Sources., 2016, 329, 50-56.

[13] B. M. Ahn, C. W. Ahn, B. D. Hahn, J. J. Choi, Y.D. Kim, S. K. Lim, K. Y. Jung, Y. C. Park, J. H. Choi, Compos. B. Eng., 2019, 168, 442-447.

[14] X. Lu, G. Xia, J. P. Lemmon, Z. Yang, J. Power Sources., 2010, 195(9), 2431-2442.

[15] Y. Goro, S. Kazutaka, Bull. Chem. Soc. Jpn., 1968, 41(1), 93-99.

[16] C. A. Beevers, M. A. S. Ross, Z Kristallogr Cryst Mater., 1937, 97(1-6), 59-66.
[17] Y. Yu Yao, J. T. Kummer, J. Radioanal. Nucl. Chem., 1967, 29(9), 2453-2466.

[18] J. Fally, C. Lasne, Y. Lazennec, P. Margotin, J. Electrochem. Soc., 1973, 120(1), 1292.

[19] A. P. Kroon, G. W. Schaefer, F. Aldinger, Chem. Mater., 1995, 7(5), 878-887.

[20] G. W. Schaefer, H. J. Kim, F. Aldinger, Solid State Ion., 1997, 97(1-4), 285-289.

[21] L. P. Yang, S. J. Shan, X. L. Wei, X. M. Liu, H. Yang, X. D. Shen, Ceram. Int., 2014, 40(7), 9055-9060.

[22] S. P. Butee, K. R. Kambale, M. Firodiya, Process. Appl. Ceram., 2016, 10(2), 67-72.

[23] S. J. Shan, L. P. Yang, X. M. Liu, X. L. Wei, H. Yang, X. D. Shen, J. Alloys Compd., 2013, 563, 176-179.

[24] H.C. Park, Y.B. Lee, S.G. Lee, C.H. Lee, J.K. Kim, S.S. Park, Ceram. Int., 2005, 31(2), 293-296.

[25] X. Lu, Guosheng Li, Jin Y. Kim, John P. Lemmon, Vincent L. Sprenkle, ZhenguoYang, J. Power Sources., 2012, 215, 288-295.

[26] S. M. Kim, S. M. Lee, K. Y. Jung, Y. C. Park, N. U. Cho, J. H. Choi, and H. S. Kim, Bull. Korean Chem. Soc., 2015, 36(12), 2869-2874.

[27] S. T. Lee, D. H. Lee, S. M. Lee, S. S. Han, S. H. Lee, S. K. Lim, Bull. Mater. Sci., 2016, 39(3), 729-735

[28] D. H. Lee, J. S. Kim, Y. H. Kim, S. K. Lim, Materials Science/Medżiagotyra, 2021, 27(1), 68-76.

[29] S. T. Lee, D. H. Lee, S. K. Lim, Materials Science., 2019, 25(3), 328-334.

[30] D. H. Lee, S. S. Han, Y. H. Kim, S. K. Lim, J Ind Eng Chem., 2019, 76, 366-373.

[31] S. T. Lee, D. H. Lee, J. S. Kim, and S. K. Lim, Met. Mater. Int., 2017, 23(2), 246-253.

[32] D. H. Lee, S. T. Lee, J. S. Kim, S. K. Lim, Mater. Res. Bull., 2017, 96, 143-148. 